\title{
EFEKTIVITAS “PORTABLE UV DISINFECTION” DALAM MENURUNKAN ANGKA BAKTERI (Escherichia Coli spp) PADA AIR MINUM
}

\author{
Syarifudin A., Zulfikar Ali As, Gunung Setiadi \\ Poltekkes Kemenkes Banjarmasin Jurusan Kesehatan Lingkungan Banjarbaru \\ Jl. H. Mistar Cokrokusumo No. 1A Kota Banjarbaru \\ E-mail: syarif_yazid@yahoo.com
}

\begin{abstract}
Abstrak: Effectivity of "Portable UV Disinfection" to Decrease Bacterial Number (Escherichia Coli Spp) in Drinking Water. Disinfection using ultraviolet ray is faster, more accurate and chiefer. This research aims to measure the effectivity of portable UV disinfection to decrease bacterial number (E. Coli) in drinking water. This research used true experiment methods with postest only control group design on laboratory scale. Drinking water contained E. Coli taken from wheel then disinfected by ultraviolet ray. Variation of treatment included variation of water depth 10,15 , dan $20 \mathrm{~cm}$ and variation of detention time $0,1,5,10$, dan 20 minutes. The result show ultraviolet ray been able to kill $E$. Coli in drinking water. Removal efficiency of E. Coli at $10 \mathrm{~cm}$ water depth with 0, 1, 5, 10, and 20 minutes detention time were $0,0 \%, 75,0 \%, 76,2 \%, 98,0 \%$, and 98,3\% particularly. At $15 \mathrm{~cm}$ water depth, removal efficiency of $E$. Coli were 0,0\%, 36,3\%, 58,2\%, 68,0\%, dan 89,0\% particularly. At $20 \mathrm{~cm}$ water depth, removal efficiency of $E$. Coli were $0,0 \%, 56,1 \%, 77,5 \%$, $83,9 \%$, dan $88,1 \%$ particularly. Statistical test showed the number of killed bacteria based on detention time was difference significantly. The longer time to be flashed the killed bacterial more. Flash of ultraviolet ray with lumination be able to kill the bacterial more effective.
\end{abstract}

Key Words : Portable UV Disinfection; E. Coli; drinking water.

\begin{abstract}
Abstrak: Efektivitas "Portable UV Disinfection" dalam Menurunkan Angka Bakteri (Escherichia E. Coli Spp) pada Air Minum. Disinfeksi menggunakan sinar ultraviolet merupakan metode yang cepat, akurat dan ekonomis. Penelitian ini bertujuan mengukur efektivitas portable UV disinfection dalam menurunkan angka bakteri E. Coli pada air minum. Penelitian ini merupakan eksperimen murni dengan rancangan posttest yang dilakukan pada skala laboratorium. Air minum yang mengandung bakteri E. Coli diambil dari sumur gali kemudian didisinfeksi menggunakan sinar ultraviolet. Variasi perlakuan meliputi variasi ketebalan air 10, 15, dan $20 \mathrm{~cm}$ dan variasi waktu kontak 0, 1, 5, 10, dan 20 menit. Hasil penelitian menunjukan sinar ultra violet mampu membunuh bakteri E. Coli pada air minum. Prosentasi penurunan E. Coli pada ketebalan air $10 \mathrm{~cm}$ dengan waktu kontak 0, 1, 5, 10, dan 20 menit masing-masing adalah 0,0\%, 75,0\%, 76,2\%, 98,0\%, dan 98,3\%. Pada ketebalan air $15 \mathrm{~cm}$ penurunan E. Coli masing-masing 0,0\%, 36,3\%, 58,2\%, 68,0\%, dan 89,0\%. Pada ketebalan air $20 \mathrm{~cm}$ penurunan E. Coli masing-masing adalah 0,0\%, 56,1\%, 77,5\%, 83,9\%, dan $88,1 \%$. Hasil uji statistik menunjukkan jumlah bakteri yang mati berdasarkan variasi waktu kontak berbeda secara signifikan. Semakin lama waktu penyinaran yang dilakukan maka semakin banyak bakteri yang mati. Usahakan sinar UV bersinar dengan luminasi sehingga daya bunuh UV terhadap bakteri lebih efektif.
\end{abstract}

Kata Kunci : Portable UV Disinfection; Bakteri E. Coli; Air minum.

\section{PENDAHULUAN}

Proses disinfeksi dalam pengolahan air minum pada saat ini masih mengembangkan cara disinfeksi dengan menggunakan bahan kimia. Bahan kimia yang digunakan dalam proses disinfeksi adalah chlor, baik dalam bentuk larutan maupun dalam bentuk gas. Kaporit berfungsi sebagai desinfektan dan juga sebagai oksidator yang mampu mengurangi bau dan rasa, secara tidak langsung penambahan kaporit dapat menurunkan zat-zat organik lainya. Disinfeksi dengan bahan kimia (chlor) mempunyai dampak negatif terhadap kesehatan ${ }^{1}$.

Dampak yang ditimbulkan dari mengkonsumsi air minum yang mengandung chlor dalam waktu yang lama akan menyebabkan kanker (karsinogenik). 
Kandungan chlor dalam air dalam batas tertentu mempunyai pengertian dan diyakini air tersebut tidak mengandung bakteri baik pathogen maupun non pathogen. Keyakinan itu mengandung konsekuensi bahwa kita juga mengkonsumsi chlor secara terus menerus. Dari berbagai studi, ternyata orang yang meminum air yang mengandung klorin memiliki kemungkinan lebih besar untuk terkena kanker kandung kemih, dubur ataupun usus besar. Sedangkan bagi wanita hamil dapat menyebabkan melahirkan bayi cacat dengan kelainan otak atau urat saraf tulang belakang, berat bayi lahir rendah, kelahiran prematur atau bahkan dapat mengalami keguguran kandungan. Selain itu pada hasil studi efek klorin pada binatang ditemukan pula kemungkinan kerusakan ginjal dan hati ${ }^{2}$.

Berdasarkan beberapa kelemahan proses disinfeksi yang selama ini dilakukan oleh Perusahaan air minum, masih menggunakan bahan khlor, maka perlu dikembangkan cara disinfeksi lain yang tidak menggunakan bahan kimia. Cara yang dipilih dan akan dikembangkan dalam penelitian ini adalah disinfeksi menggunakan sinar ultraviolet.

\section{METODE}

Penelitian ini menggunakan metode eksperimen murni (true experiment) dengan rancangan postes dengan kelompok kontrol (postest only control group design) yang dilakukan pada skala laboratorium. Air minum yang mengandung bakteri $E$. Coli diambil dari sumur gali dan dilakukan pengujian pada unit disinfeksi sinar ultraviolet yang sudah dirancang. Penurunan angka bakteri E. Coli dilakukan dengan memvariasikan waktu detensi (waktu kontak) antara sinar ultraviolet dengan air minum, jarak (ketebalan air) pada penyinaran. Selanjutnya air minum dilakukan pemeriksaan jumlah angka bakteri E. Coli sebelum dan sesudah pemaparan. Data hasil pemeriksaan angka bakteri dilakukan analisis regresi dan Anova. Dari penelitian ini akan didapatkan waktu kontak optimum dan ketebalan air optimal dalam menurunkan angka bakteri E. Coli. Dari penelitian ini akan didapatkan waktu kontak dan ketebalan air yang tepat dalam menurunkan angka bakteri $E$. Coli pada air minum.

Pemilihan waktu kontak 0, 1, 5, 10, dan 20 menit dengan alasan waktu aktif penyinaran dan reaksi DNA bakteri terhadap UV. Sedangkan ketebalan air 0, $10,20,30 \mathrm{~cm}$ berdasarkan jarak gelombang dan panjang gelombang yang mampu mereaksi DNA bakteri. Analisis data menggunakan bantuan program komputer SPSS series, dengan uji statistik Analysis of Variance (ANOVA) two way.

Eksperimen dilakukan dengan langkah-langkah sebagai berikut:

1. Pembuatan alat "Portable UV Disinfection".

2. Pemilihan air minum yang akan diuji.

3. Uji coba peralatan yang dibuat.

4. Memeriksa angka bakteri E. Coli pada air minum sebelum diolah.

5. Melakukan disinfeksi dengan "Portable UV Disinfection".

6. Melakukan pengulangan dengan berbagai variasi disinfeksi dengan "Portable UV Disinfection".

7. Memeriksa angka bakteri E. Coli pada air minum setelah diolah.

8. Menganalisis dan menyimpulkan hasil penelitian.

\section{HASIL DAN PEMBAHASAN \\ Kualitas air sumur gali}

Kualitas air sumur gali yang diambil sebagai sampel dalam penelitian ini telah diperiksa di Laboratorium Jurusan Kesehatan Lingkungan Poltekkes Kemenkes Banjarmasin dengan hasil seperti disajikan pada tabel 1. Pada pemeriksaan sampel air sumur gali sebelum dilakukan penyinaran dengan Ultra violet terlihat angka Bakteri E. Coli pada air sumur gali yang dipakai sebagai bahan baku sebelum dilakukan perlakuan mempunyai nilai bakteri golongan E. Coli sangat tinggi, melebihi standart kualitas air minum berdasarkan Peraturan Menteri Kesehatan Republik Indonesia Nomor 492/Menkes/ PER/IV/2010 tentang persyaratan Kualitas Air Minum. Tingginya jumlah bakteri pada air sumur gali dapat terjadi dari berbagai sumber seperti udara, tanah, sampah, lumpur, tanaman hidup atau mati, hewan hidup atau mati (bangkai), 
kotoran manusia atau hewan, bahan organik lainnya, dan sebagainya. Mikroorganisme tersebut mungkin tahan lama hidup di dalam air, atau tidak tahan lama hidup dalam air karena lingkungan hidupnya yang tidak cocok ${ }^{3}$.

Tabel 1. Rekapitulasi Hasil Penelitian sebelum dilakukan Penyinaran Ultra Violet terhadap Angka Bakteri E. Coli pada Air Sumur Gali

\begin{tabular}{cccccccccc}
\hline \multirow{2}{*}{ Waktu kontak } & \multicolumn{3}{c}{$10 \mathrm{~cm}$} & \multicolumn{3}{c}{$15 \mathrm{~cm}$} & \multicolumn{3}{c}{$20 \mathrm{~cm}$} \\
\cline { 2 - 10 } & U1 & U2 & U3 & U1 & U2 & U3 & U1 & U2 & U3 \\
\hline \multirow{2}{*}{0 menit } & 16000 & 16000 & 9200 & 2200 & 3500 & 3400 & 1700 & 2200 & 1800 \\
\hline
\end{tabular}

Sumber : Hasil pemeriksaan Lab Jurusan Kesehatan Lingkungan Poltekkes Kemenkes Banjarmasin

Keterangan : U = Ulangan

\section{Hasil Pengolahan Air Sumur Gali}

Pengolahan air sumur gali dilakukan dengan melakukan kontak dengan sinar Ultra Violet dengan variasi waktu kontak
1 menit, 5 menit, 10 menit, dan 20 menit, sedangkan variasi ketebalan air $10 \mathrm{~cm}, 15$ $\mathrm{cm}$, dan $20 \mathrm{~cm}$. Hasil penurunan angka bakteri E. Coli dapat dilihat pada tabel 2.

Tabel 2. Rekapitulasi Hasil Penelitian Efek Penyinaran Ultra Violet terhadap Angka Bakteri E. Coli pada Air Minum

\begin{tabular}{cccccccccc}
\hline \multirow{2}{*}{ Waktu kontak } & \multicolumn{3}{c}{$10 \mathrm{~cm}$} & \multicolumn{3}{c}{$15 \mathrm{~cm}$} & \multicolumn{3}{c}{$20 \mathrm{~cm}$} \\
\cline { 2 - 10 } & $\mathrm{U} 1$ & $\mathrm{U} 2$ & $\mathrm{U} 3$ & $\mathrm{U} 1$ & $\mathrm{U} 2$ & $\mathrm{U} 3$ & $\mathrm{U} 1$ & $\mathrm{U} 2$ & $\mathrm{U} 3$ \\
\hline 1 menit & 3500 & 3400 & 3400 & 1700 & 2300 & 1800 & 700 & 1100 & 700 \\
\hline 5 menit & 3300 & 3400 & 3100 & 1100 & 1400 & 1300 & 460 & 330 & 490 \\
\hline 10 menit & 270 & 310 & 260 & 1100 & 940 & 790 & 310 & 340 & 270 \\
\hline 20 menit & 220 & 200 & 260 & 460 & 310 & 230 & 220 & 260 & 200 \\
\hline
\end{tabular}

Sumber : Hasil pemeriksaan Lab Jurusan Kesehatan Lingkungan Poltekkes Kemenkes Banjarmasin.

Keterangan : $\mathrm{U}=$ Ulangan

Tabel 2 menunjukkan kualitas air sumur gali setelah dilakukan penyinaran menggunakan sinar Ultra Violet terjadi penurunan terhadap bakteri E. Coli dibandingkan dengan kualitas air sumur gali sebelum dilakukan perlakuan. Penurunan angka bakteri $E$. Coli terjadi karena adanya Radiasi sinar ultraviolet yang dihasilkan merupakan suatu sumber energi yang mempunyai kemampuan untuk melakukan penetrasi ke dinding sel mikroorganisme dan mengubah komposisi asam nukleatnya. Absorbsi ultraviolet oleh DNA (atau RNA pada beberapa virus) dapat menyebabkan mikroorganisme tersebut tidak mampu melakukan replikasi akibat pembentukan ikatan rangkap dua pada molekul-molekul pirimidin. Sel yang tidak mampu melakukan replikasi akan kehilangan sifat patogenitasnya. Radiasi ultraviolet yang diabsorbsi oleh protein pada membran sel akan menyebabkan ke- rusakan membran sel dan kematian sel ${ }^{4}$. Radiasi UV dapat membunuh bakteri secara efektif. Spektrum cahaya dengan intensitas tinggi mempunyai pengaruh yang paling utama dalam kematian sel. Irradiasi UV ini dapat menyebabkan kerusakan DNA. Basa purin dan pirimidin sebagai materi dasar DNA menyerap radiasi UV yang terbanyak, dan penyerapan maksimum untuk DNA dan RNA terjadi pada panjang gelombang UV $260 \mathrm{~nm}^{5}$. Gangguan pada DNA ini dapat menyebabkan kematian sel. Penyinaran UV juga dapat menyebabkan beberapa efek kerusakan lain seperti aliran ion yang abnormal, peningkatan permeabilitas membran dan depolarisasi membran sel. namun perlu diperhatikan bahwa beberapa mikroba khususnya bakteri memang mempunyai suatu sistem metabolik fungsional yang bervariasi dalam mekanisme untuk memperbaiki 
kerusakan asam nukleatnya. Adanya kemampuan mikroba untuk memperbaiki kerusakan selnya

Pengaruh Penyinaran Ultra Violet terhadap Angka Bakteri E. Coli pada Air Sumur Gali

Dari hasil pemeriksaan sampel air sumur gali yang tertera pada tabel 1. yang kemudian dilakukan pengolahan secara fisika yaitu dengan Penyinaran dengan Ultra Violet dan dilakukan waktu kontak antara 0-20 menit dengan ketebalan air antara $10-20 \mathrm{~cm}$. Hasil pengolahan air sumur gali kemudian dilakukan pemeriksaan di laboratorum Jurusan Kesehatan Lingkungan Politeknik Kementerian Kesehatan Banjarmasin dengan hasil seperti pada gambar 1 dan 2.

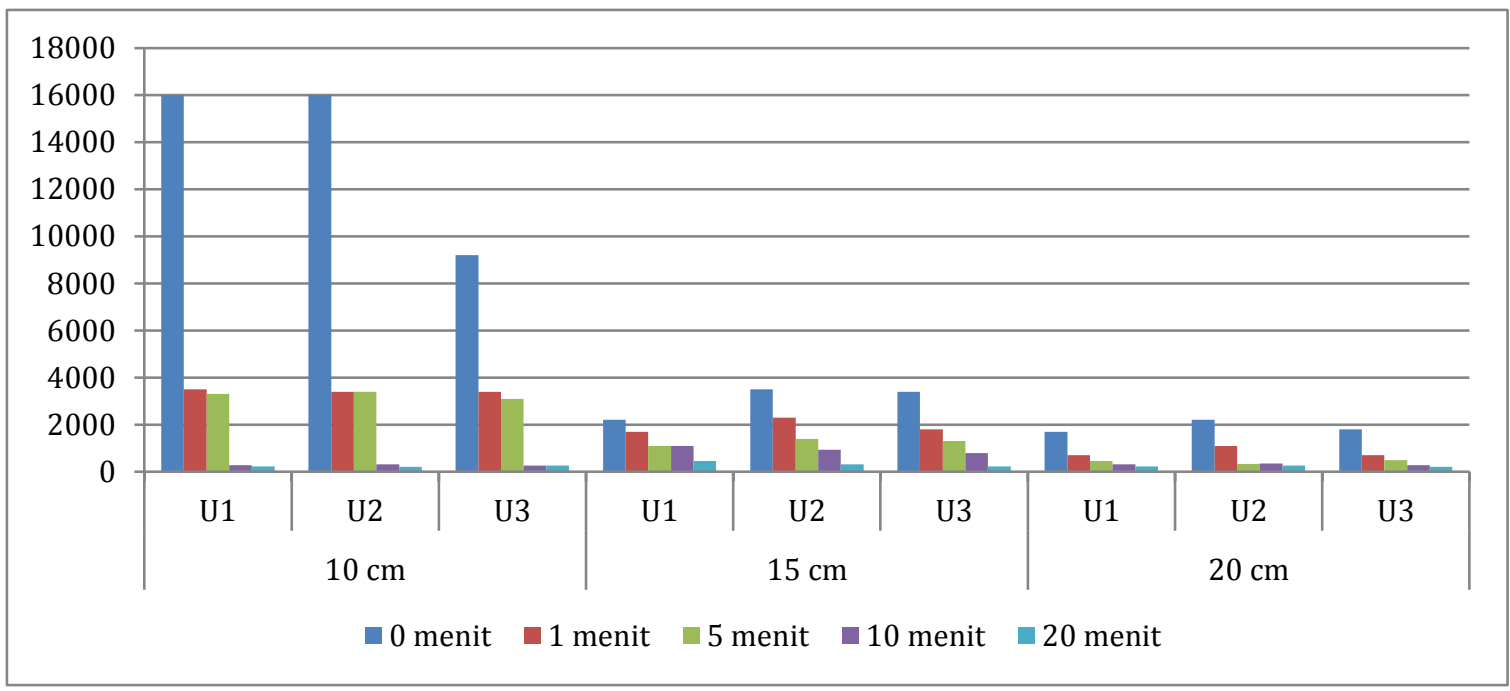

Gambar 1. Pengaruh Penyinaran Ultra Violet terhadap Angka Bakteri E. Coli pada Air Sumur Gali

Selanjutnya efek perlakuan menurut variasi waktu kontak dan ketebalan terhadap penurunan rata-rata jumlah bakteri dapat dilihat pada grafik 2. Dari gambar tersebut terlihat penurunan angka Bakteri E. Coli pada air sumur gali setelah dilakukan kontak dengan sinar ultra violet dalam waktu maksimal 20 menit

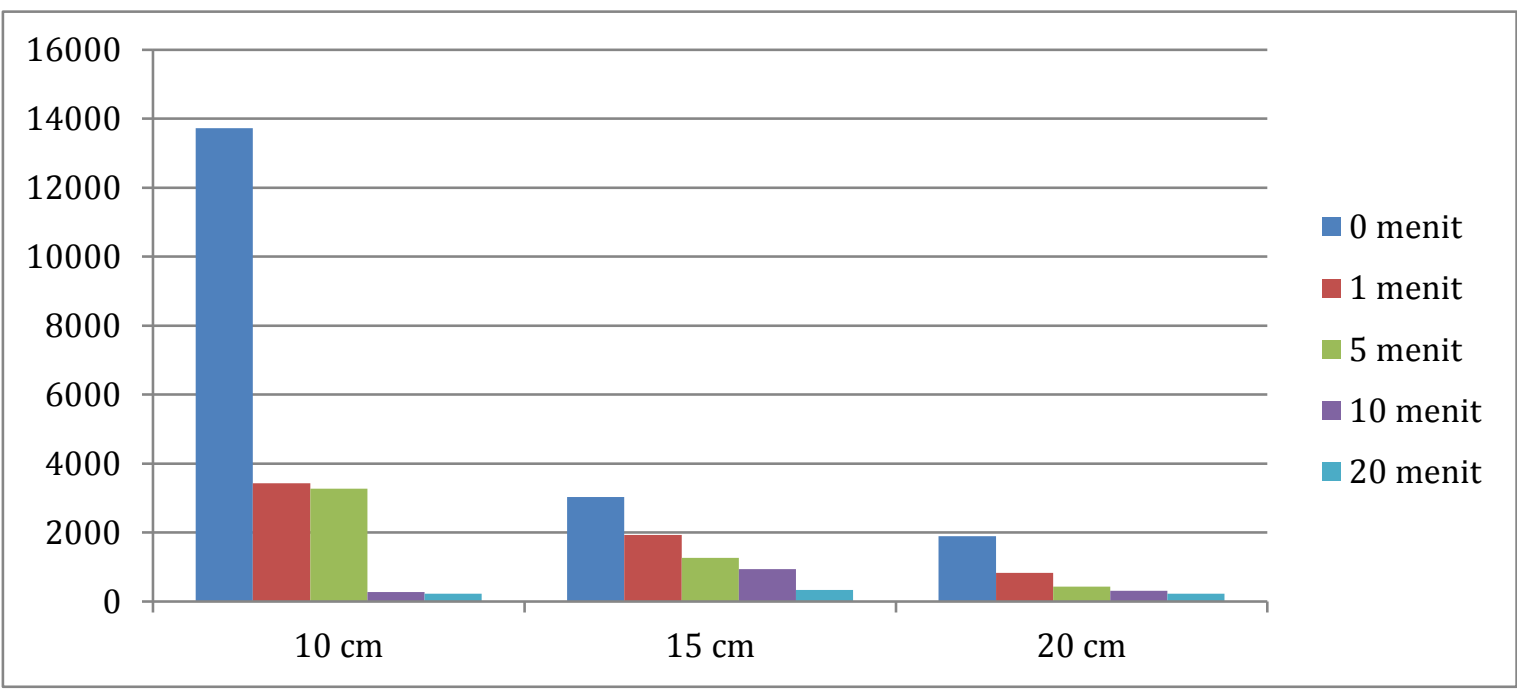

Gambar 2. Pengaruh Penyinaran Ultra Violet terhadap Rata-rata Angka Bakteri E. Coli Menurut Waktu Kontak 

Perbedaan penurunan Angka Bakteri E. Coli terlihat signifikan menurut waktu kontak dengan variasi, $0,1,5,10$ dan 20 menit. Hal ini disebabkan lamanya kontak dengan sinar ultra violet sangat mempengaruhi kehidupan bakteri E. Coli. Semakin lama pemaparan yang diberikan pada ketebalan sampel air yang rendah, maka reduksi E. Coli akan semakin besar pula.

Dari Hal ini karena ketebalan sampel air yang rendah lebih memudahkan pemaparan UV secara merata, didukung juga dengan semakin lamanya waktu pemaparan. Tingkat inaktifasi mikroorganisme sangat tergantung pada dosis UV yang digunakan. Kinetika inaktifasi mikroorganisme pada desinfeksi menggunakan ultraviolet. Efek perlakuan menurut variasi ketebalan terhadap penurunan rata-rata jumlah bakteri $E$. Coli dapat dilihat pada grafik 3. di bawah ini:

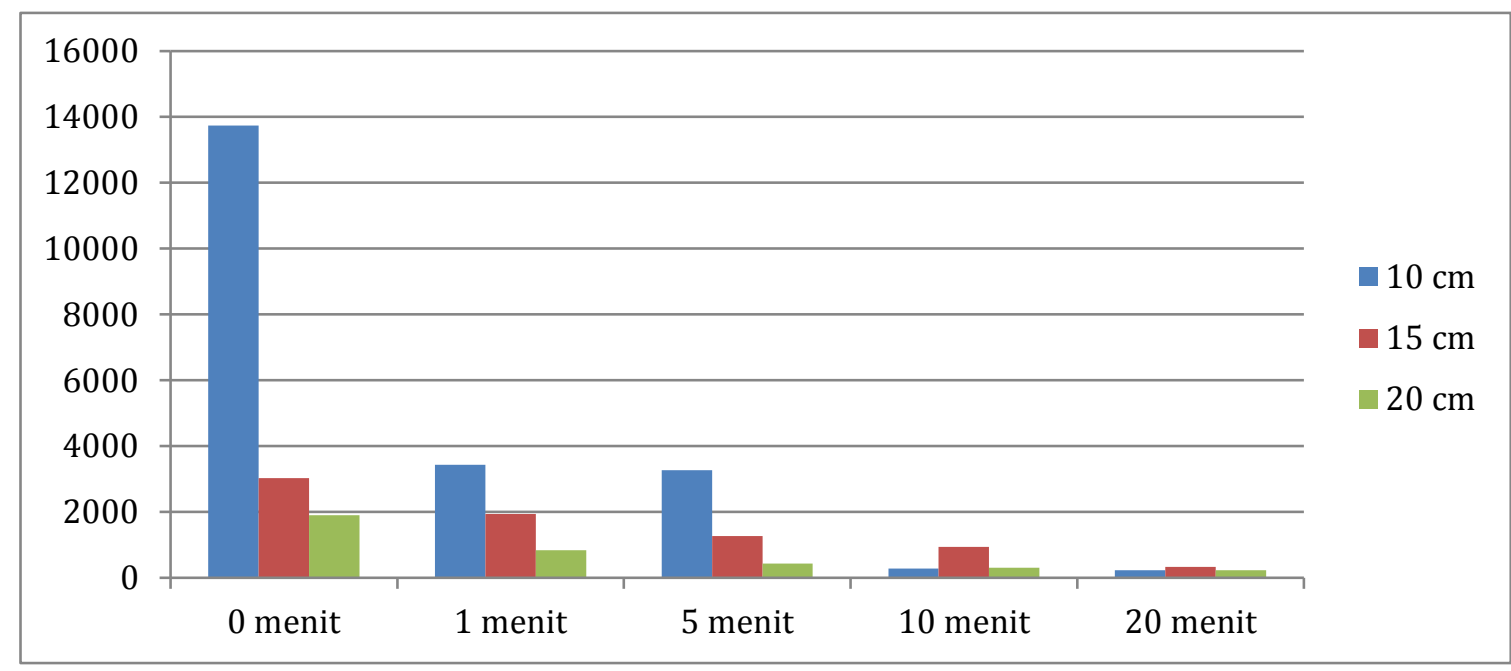

Gambar 3. Pengaruh Penyinaran Ultra Violet terhadap Rata-rata Jumlah Bakteri Menurut Ketebalan air

Dari grafik 3. terlihat penurunan Angka Bakteri E. Coli terhadap ketebalan air setelah dilakukan Penyinaran Ultra Violet. Penurunan bakteri E. Coli tidak signifikan, hal ini disebabkan waktu pengambilan contoh air yang akan diuji tidak pada saat yang bersamaan. Meskipun demikian, karena pengujian dengan variasi waktu kontak dilakukan pada saat yang bersamaan (contoh air yang sama). Untuk lebih jelas, efek penyinaran ultra violet terhadap jumlah bakteri dalam air minum dikonversi dalam bentuk prosentase penurunan seperti tergambar pada grafik 4 . Dari gambar tersebut terlihat penurunan Angka Bakteri E. Coli pada sampel air sumur gali setelah kontak dengan sinar Ultraviolet, kemampuan sinar ultra violet dalam membunuh bakteri $E$. Coli pada air minum diuji berdasarkan dua variasi perlakuan yaitu ketebalan air $10 \mathrm{~cm}, 15$ $\mathrm{cm}$, dan $20 \mathrm{~cm}$ sedangkan waktu kontak 0 menit, 1 menit, 5 menit, 10 menit, dan 20 menit. Selanjutnya variasi kedua perlakuan diulang sebanyak tiga kali. Prosentasi penurunan daya bunuh sinar UV terhadap bakteri E. Coli pada ketebalan air $10 \mathrm{~cm}$ dengan waktu kontak 0 menit 0,0\%, 1 menit 75,0\%, 5 menit 76,2\%, 10 menit 98,0\%, 20 menit 98,3\%. Pada ketebalan air $15 \mathrm{~cm}$ waktu kontak 0 menit $0,0 \% 1$ menit $36,3 \%, 5$ menit 58,2\%, 10 menit 68,0\%, 20 menit 89,0\%, sedangkan ketebalan air $20 \mathrm{~cm}$ dengan waktu kontak sinar UV 0 menit $0,0 \% 1$ menit $56,1 \%, 5$ menit 77,5\%, 10 menit 83,9\%, 20 menit $88,1 \%$. Hal ini menunjukan semakin tipis ketebalan air, dan waktu yang lama semakin efektip pula daya bunuh sinar ultraviolet terhadap bakteri E. Coli. Efektifitas sinar ultra violet terhadap daya bunuh bakteri dipengaruhi oleh beberapa factor diantaranya: Intensitas cahaya yang digunakan, jarak sumber cahaya terhadap bakteri, lama waktu penyinaran, jenis bakteri itu sendiri6. 



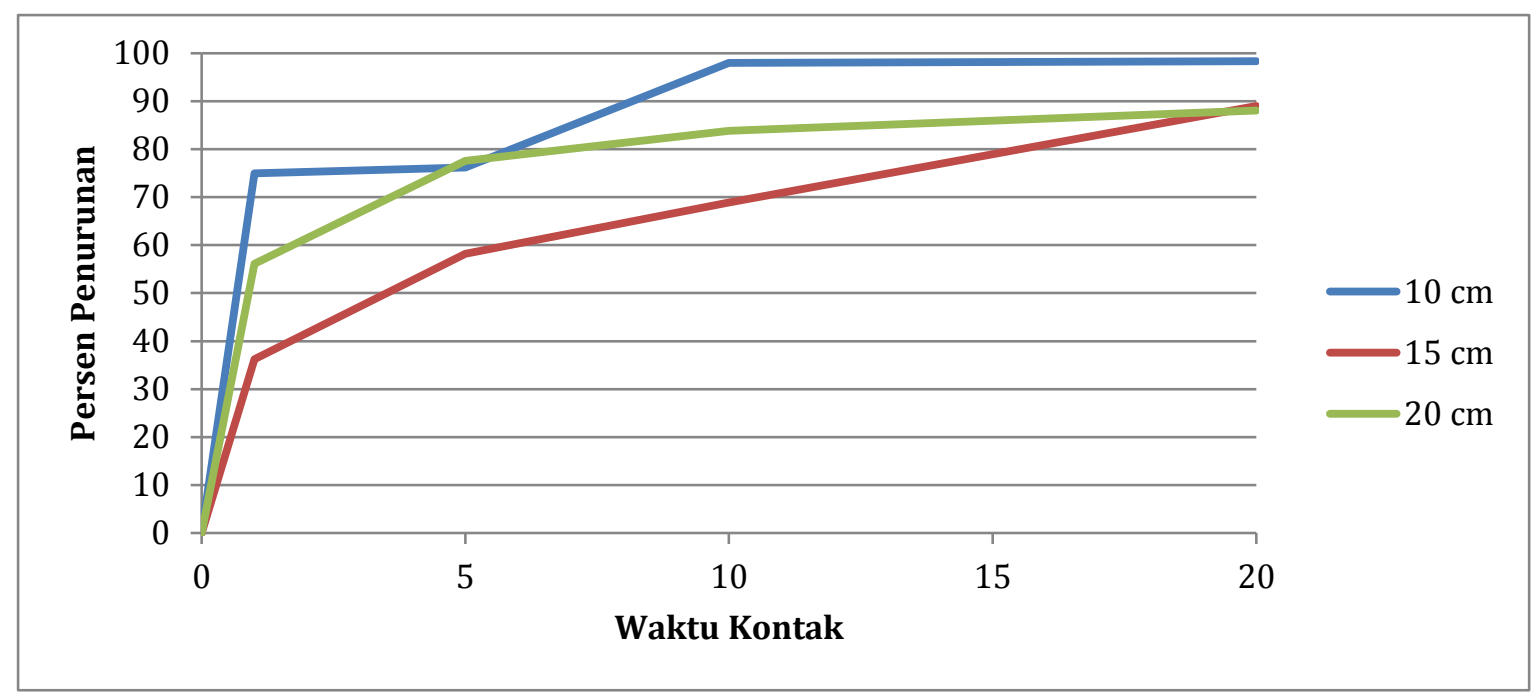

Gambar 4. Prosentase Penurunan Jumlah Bakteri pada Air Minum akibat Penyinaran Ultra Violet menurut Ketebalan dan Waktu Kontak

Untuk membuktikan efek variasi perlakuan terhadap penurunan Angka Bakteri E. Coli pada air sumur gali, dilakukan analisis faktorial menunjukkan penurunan jumlah bakteri akibat penyinaran ultra violet berdasarkan variasi ketebalan, waktu kontak maupun interaksi ketebalan dan waktu kontak berbeda secara signifikan pada tingkat kepercayaan 95\%.

Perbedaan jumlah bakteri menurut ketebalan air disebabkan waktu pengambilan contoh air yang akan diuji tidak pada saat yang bersamaan. Meskipun demikian, karena pengujian dengan variasi waktu kontak dilakukan pada saat yang bersamaan (contoh air yang sama), maka perbedaan ketebalan tersebut tidak berpengaruh terhadap penilaian hasil uji. Perbedaan penurunan jumlah bakteri juga terlihat signifikan menurut waktu kontak dengan variasi, $0,1,5,10$ dan 20 menit. Untuk melihat lebih jauh perbedaan pada masing-masing variasi waktu kontak dilakukan multiple comparison menggunakan uji beda nyata terkecil atau uji least significant difference (LSD) dengan. Hasil uji membuktikan bahwa setiap variasi waktu kontak memberikan efek penurunan jumlah bakteri yang signifikan. Artinya semakin lama waktu penyinaran yang dilakukan maka semakin banyak jumlah bakteri yang mampu dibunuh, dan perbedaannya bermakna secara statistik.

\section{KESIMPULAN DAN SARAN}

Kesimpulan yang didapat dari penelitian Efektivitas "Portable UV Disinfection" Dalam Menurunkan E. Coli Pada Air Minum adalah sebagai berikut: Penggunaan sinar Ultra violet dapat menurunkan jumlah bakteri E. Coli prosentasi penurunan mencapai 98,3\% dengan waktu detensi (contact time) UV terhadap air secara optimal 20 menit. Ketebalan air yang tepat dalam proses UV disinfektion dalam menurunkan angka bakteri E.E. Coli pada ketebalan $10 \mathrm{~cm}$. Semakin lama pemaparan yang diberikan pada ketebalan sampel air yang rendah, maka efektivitas reduksi terhadap bakteri E.E. Coli akan semakin besar.

Penelitian ini dapat dijadikan sebagai bahan informasi untuk melak-sanakan program pengawasan terhadap kualitas air minum pada depot air minum isi ulang khususnya Dinas Kesehatan. Saran bagi penelitian selanjutnya tentang pengujian sinar Ultraviolet terhadap daya bunuh bakteri E. Coli, dengan mempertimbangkan ketebalan kontak air dengan sinar UV dapat kontak secara oftimal. Usahakan sinar UV bersinar dengan luminasi sehingga daya bunuh UV terhadap bakteri lebih efektif. 


\section{DAFTAR PUSTAKA}

1. Darpito, Hening dkk (1997) Pedoman Teknis Grading Penyediaan Air Sistem Perpipaan. Dekjen P2M dan PLP Depkes RI. Jakarta.

2. Effendi H, 2003, Telaah Kualitas Air Bagi Pengelolaan Sumber Daya dan Lingkungan Perairan, Kanisius, Yogyakarta.

3. Fardiaz, S., 1992, Mikro Pangan I, PT Gramedia Pustaka Utama, Jakarta.
4. Hollaender, A. 1995, Radiation Biology. Vol I L Effects Of Radiation On Bacteria. Cornell University, Itacha N.Y.

5. Anderson, John G., 2000, Inactivation of Food-Borne Enteropathogenic Bacteria and Spoilage Fungi Using Pulsed-Light, IEEE Transaction on Plasma Science, Vol.28, No. 1, February 2000.

6. Bryant, E.A., George P.F., George C.B. , 1992, Disinfection Alternatives for Save Drinking Water, Van Nostrand Reinhold, New York. 
2 | Jurnal Kesehatan Lingkungan Vol. 11 No.2 Juli 2014 